\title{
Prodevelopmental Orientation as a Determinant of an Active Cooperation of a Subject for the Benefit of Constructing One's Own Career
}

\author{
KEY WORDS \\ career, \\ prodevelopmental \\ orientation, \\ developmental \\ potential, career \\ construction, career \\ development
}

\begin{abstract}
Cybal-Michalska Agnieszka, Prodevelopmental Orientation as a Determinant of an Active Cooperation of a Subject for the Benefit of Constructing One's Own Career [Orientacja prorozwojowa jako determinant aktywnego współdziałania podmiotu na rzecz konstruowania własnej kariery]. Kultura - Społeczeństwo - Edukacja nr 2, 2012, Poznań 2012, pp. 41-52, Adam Mickiewicz University Press. ISBN 978-83-232-2528-7
\end{abstract}

The orientation of a contemporary society towards a global career creates the need of rebuilding the frames of human activity and innovation. The most important is active participation and cooperation in a reality undergoing a permanent change. Conceptualization of quality new apprehension of career issues as an individual's possession indicates a many-sided character of a contemporary discourse, which combines implications of an interdisciplinary dialogue and creates the need to review theoretical reflection about the way of understanding career and conditions, as well as indicators of its formation and construction.

The "prodevelopmental orientation" is a remedy for a contemporary human being to be oneself again in this situation in the world of careers. In this attitude towards the definition of "a career", one underlines importance of constructing (not choosing) a career for designing a quality of life.

The spirit of the times implies yielding to individualistic tendencies, the disintegration of individualistic life projects; what we have instead is "the kaleidoscope of independent episodes" (Z. Bauman). But on the other hand, as G. Lipovetsky emphasizes, „not having any aim or roots, any substance or horizons in the presence of which it could interchangeably define itself, individualism can now grow freely, sprouting in every possible direction”. „Our fragile world” (R. Kapuściński) 
demands to look at world as "a human reality”, whose task is to look, simultaneously, at „a man in the world of career” and at „a world of career in a man”.

Trying to specify the term "career", it is difficult not to notice lack of acuteness and ambiguity in the semantic senses ascribed to the term. Moreover, the diversity of meanings, in which this term is used, is a distinguishing feature when one thinks about careers. The range of the term career may be its subjective and objective meaning structure, evaluative (also in a negative way, such as , a careerist”, „careerism”) and non-evaluative (which is also a determinant of thinking about career as an individual's "property") understanding or capturing of this issue from an organization or a subject perspective. On the basis of known theories of career development, it is worth recalling at least theoretical perspective presented by Miller and Form (1951), D.T. Hall and Nougoim (1968), D. Super (1980), J.G. Greenhouse and G. A. Callalan (1994), A. Paczkowski (1998) (Wołk, 2009: 20-21), A. Kargulowa (2005), J. Szczupaczyński, Miller-Tiedeman and Tiedeman (1990), which says that ,the career development starts with a beginning of life and lasts continuously until the end of it" (Wołk, 2009: 20). The career development process is, as Sears (1982) ascertains, „a sum of constellations of psychological, sociological, educational, physical, economic and accidental factors, which are linked with one another in order to shape an individual's career during his/her lifetime" (Patton, McMahon, 2006: 6).

A contemporary career definition does not limit oneself only to aspects linked with promotions, having a specific profession, a satisfactory professional situation or stability of inner relations in a profession that one practises. A much broader range of things that denote and connote the term "career” also includes ,apart from purely professional situation (...) a level of mental well-being, understood as lack of tensions, which disorganise an individual's activities, economic and social affluence and a successful family situation" (Bańka, 2005a: 8).

Probably the most characteristic stream of considerations focused on a subjective career aspect (together with stressing its objective aspect, which is characteristic of interactionism) is the category of "moral career”, which is presented by Goffman. Such a career is understood as an individual's reactions to oneself in specific situations, which lead to permanent changes in the concept of one's Self. In the presented theoretical orientation, one stresses the examination of a career in an inner dimension, which means examining changes in a subject's identity and his/ her ideas about oneself and other subject of a social life (Rokicka, 1992: 125).

In the contemporary apprehension of career, one emphasizes importance of activities which are not directly linked with a given job. These activities are free

1 The term "career” is also, as Z. Bauman systematized, a moral term, linked with a specific style of evaluating attitudes to life, relations with the environment, as well as duties that result from these relations (Bauman, 1960: 25). 
time activities, forms of recreation, education or family roles which are connected with employment (Bańka, 2005b: 26). In this less restrictive attitude towards the definition of ,a career”, one underlines importance of constructing (not choosing) a career for designing a quality of life (Maree, 2010: 362). According to D.T. Hall, a career understood in this way, means a sequence of an individual's experiences (experiences which are understood as „shaping inner individual processes, such as: ambitions and aspirations, satisfaction, imaginings about oneself, attitudes toward work, which are influenced by constantly changing roles") (Miś, 2006: 477), linked with an individual's professional role, which constitutes an individual's professional life history. As A. S. King (1999) puts it, „psychological strength of one's own identity, insight and persistence in striving for realization of career goals represent the main components of motivation and "dedication" (understood as commitment - A.C-M) to a career, as well as cooperation and cohesiveness (...) in an organization" (Adekola, 2011: 104). An individual gives specific individual meanings to chosen elements of a reality, thanks to an ability to read cultural codes. Individuals create their own individual history and they have a history ahead of them. An individual constructs one's own life and, at the same time, one's own personal career ,through identification (giving meanings) through one's own professional behaviours and numerous experiences in workplaces" (Maree, 2010: 363), attaching, at the same time, importance to the context, in which these experiences occur. Taking responsibility for seeking a meaning of one's role in a given profession, that has its source in, according to Ch. Handy, the author of The Age of Paradox: a direction (an individual feeling of action for a good cause), continuity (a subject's faith in the continuance of one's own work) and inclusiveness (being a part of a community that an individual identifies oneself with and that he or she concretes), is a lifelong process and a task for lifelong learning (Zarzadzanie kariera, 2006: 11). This British scientist adds that „a meaning will come to those, who develop one's own sense of direction, continuity and inclusiveness" (Biolos, 2006: 30) in their professional practice.

A prodevelopment orientation plays an important role in job world and career planning and career management. A context, in which one uses the notion „orientation", means in a broad sense the ability to assess, discern and interpret a situation, the knowledge of facts and leaning towards something (see: Kopaliński, 1994: 368; Sikorska-Michalak, Wojniłko, 1998: 688). This term is sometimes defined as "ability to proper and quick establishment of external data and the data linked with oneself and with the direction of one's deliberate action" (Hejnicka-Bezwińska, 1991: 16). The link between orientation and physical activity of an individual and, especially, with their attitude towards the surrounding world was S. Błachowski's subject of research. The author defined orientation as a primitive predisposition formed as a result of evolution. S. Szuman linked orientation with 
an action understood as a task, which has to be successfully solved to achieve a planned goal. A. Lewicki uses a different definition of orientation. He claims that orientation is , a direct basis for an action (retrospection), which he attributes with an important meaning for forming experience as a basis for future actions" (Hejnicka-Bezwińska, 1991: 16). According to him, orientation has not only a descriptive component but also an evaluative one. K. Skarżyńska presented a definition of psychological orientation, while describing an egalitarian and not egalitarian orientation. According to her, orientation is „more or less cohesive set of cognitive orientations, as well as motivating and moral ones towards a given situation (determined by a kind of an interpersonal reaction), which serves as a guide for individual actions in a given situation" (Skarżyńska, 1990: 139). S. Gerstmann paid attention to the relation between orientation and knowledge. He described orientation as the third, next to scientific knowledge (theoretical, organised) and popular knowledge (practical, everyday), source of information about a man and the surrounding reality. In this definition, orientation combines the above mentioned types of knowledge with action. Orientation, that takes into consideration action, contains information about, on the one hand, the surrounding (orientation in the conditions of action), on the other hand, the subject of action (orientation in itself). With these assumptions in mind, the same author divided global orientation. He singled out a general orientation, typological - situational and situational. The first of these three forms itself during childhood, under the influence of upbringing but it undergoes modifications during the whole life of an individual. Thanks to it an individual formulates aims and ways of achieving them. The typological - situational orientation indicates the importance of aims, tasks and the feeling of awareness of social importance. The situational orientation depends on the content of general and typological - situational orientation. It refers to facts and individual happenings. Taking into consideration the above assumptions, one may assume that orientation determines attitudes and these attitudes lead directly to behaviour. M. Ziółkowski's considerations on the subject of orientation correspond with the above conclusion. In this context, he defines orientation as generalized tendencies to perceive, judge (an individual has a system of values, as well as, categories of values), feel and react to social reality (the author assumes that the subject can define, order and react properly to the surrounding only when he can include it into a general category, not necessarily with full consciousness of the process). One may, thus, assume, that orientations consist of, not only, "lucid, clear and conscious convictions, but they also have convictions that are only partially conscious, premonitions and feelings which are often on the verge of unconsciousness" (Ziółkowski, 1990: 57). Fundamental elements that make up the notion of orientation are values, popular knowledge, evaluation and predisposition towards behaviours. 
The nature of prodevelopmental actions, in the general perspective, constitutes actions (of an individual) concentrated on the realization of a certain vision of an ideal state. T. Zysk, citing W. Reykowski and J. Kozielecki, emphasized that the most essential and characteristic feature of a human mind is the ability to formulate the vision of future state of things. The subject is convinced of the perfection of this state and takes action aiming at achieving it (Zysk, 1990: 199).

What are the psychological characteristics conditioning prodevelopmental behaviours? T. Zysk mentions here: inner motivation, attitude towards the future and active coping with the reality ${ }^{2}$. He ascribed special meaning to the first two factors.

The inner motivation (defined as "growth" or aspiration) is determined by the vision of the ideal state and is most often characterized as an engagement of an individual in some kind of an action because it gives the subject pleasure or because it arouses the subject's interest. Motivations are obviously linked with revealing and fulfilling needs. Motivation can be also defined as a behavioral term. Deci and Ryan (Zysk, 1990: 199) describe inner motivation in this way, defining it as behaviours that may occur and be sustained, even when there are no visible reinforcements of two fundamental factors: the need for competence and self-determination. The need for competence is linked with the need for rivalry, with a cognitive curiosity and with a tendency to show perfection in action. The self-determination may be identified with the feeling of being the author of things, the shaping of responsibility in an individual. The subject does not concentrate of the "fate" but on the independent creation of one's future, that is on the "choice". It is accompanied by an antifatalistic attitude (Sarapata, 1993: 24).

J. Kozielecki characterises the inner motivation, which constitutes the basis for the prodevelopmental orientation, as a heterostatic motivation, which is determined by a set of inner reinforcements. He assumes that it is based on keeping divergence between the present (real) state and a desired (ideal) state. Keeping this divergence is a source of satisfaction for the subject and it results from the inner mechanisms of an individual ${ }^{3}$.

The attitude towards future is the second important element (next to motivation) in shaping prodevelopmental behaviours. J. Kozielecki thinks that the temporal orientation, that is the ability of an individual mind to formulate visions of future states of things, is a basis for prodevelopmental behaviours. He emphasizes

2 Thanks to outlining the model of prodevelopmental orientation, one can characterize the model of non-developmental attitude. It will be based on: outside motivation, attitude towards the future or the present time and passive coping with reality (Zysk, 1996: 206).

3 The autor opposes heterostatic and homeostatic motivation. The characteristic feature of the homeostatic motivation is that an individual aims at restoring balance between reality and the desired state. The most important thing is the reduction of tension (Zysk, 1990: 200). 
that "the most fundamental and, at the same time, the most characteristic feature of a human mind is the ability to formulate visions of future states of things, about which an individual is convinced that they are better, more perfect than the present ones. Moreover, an individual is ready to take action aiming at achieving them, despite the appearance of many objective obstacles. Actions that aim at accomplishing the vision, through changing and subduing the reality, seem to constitute the nature of prodevelopmental actions". The author points out the transgressional nature of a human mind, the tendency to go beyond ,what one is and what one has" (Zysk, 1990: 199). It is assumed that the temporal orientation, with an assumption of properly formulated state of perfection, guides an individual to activity, which favours developmental and creative actions. W. Łukaszewski pays attention to the fact that the temporal orientation has to have realistic and instrumental features (Zysk, 1990: 201-202) in order to constitute a significant element of prodevelopmental actions of a subject. He distinguishes - in accordance with a classical understanding of time - three types of temporal orientation: retrospectivism, presentism ${ }^{4}$ and futurism. There may also occur a compilation of those three, then an individual turn to the whole horizon of time (Łukaszewski, 1984: 178). Planning - as A. Sarapata emphasises - characterises active people, who control their own fate, prudent, far-sighted, accomplishing their goals and tasks. In this category one may also mention the individual's interest in the matters of their own country, continent and the world. Active coping with the reality displays itself in an active reshaping of a present state aiming at the realization of a vision of ideal states. Diaz-Guerri in his research distinguished two styles of dealing with problems: active (an individual makes changes in a social surrounding, in a way of influencing reality) and passive (a subject adapts to the changes that take place in the surrounding reality). He stresses that active dealing with reality „takes place, not only, in situations when an individual is responsible for what he does and what happens around him but, also, when the responsibility is subscribed to someone else. The essence of active coping with reality is, also, dealing with the results of someone else's actions, not only one's own ones" (Zysk, 1990: 203). The subject handles the surrounding reality in an active way. He is convinced that there is a possibility of influencing the change of a situation; he has a great sense of power. An active individual is also characterized by the need of achievements, which manifests itself in , a constant aiming at achieving the best results in conditions of competition, innovative predispositions, a constant will to take rational decisions, that is, for example, to foresee the results of risk, a constant tendency to objective analysis and judgment of one's own actions" (Sarapata, 1993: 24).

${ }^{4}$ To find more about the subject of presentistic orientation in the plans of youth, see: Zandecki, 1996. 
The notion of prodevelopmental orientation is, thus, a broad term, that includes different dimensions of the term „development"s.

The essence here is a sequential development of individuals (integrally linked with a development of their careers) through their whole life. Not accidentally, looking at a cognitive practice in a construction of a career counseling model, V.G. Zunker ascribes a key role in designing a life that is integrated with a career construction to: a subject's perception of success, a subject's motivation to work, an individual's need of inner satisfaction, roles, a quality of relations with other life partners, developmental and contextual changes (Maree, 2010: 364). As J.H. Greenhaus stresses, „a career” is shown here as „a pattern of experiences linked with work, which holds together and determines a fundamental direction in an individual's life" (Bańka, 2005: 24). In this sense, quoting J. Arnold, one may say that "a broad approach to career assumes that it is a sequence of positions linked with employment, roles, activities and experiences" (Bańka, 2005: 24) that subjects gain throughout their lifelong development.

A cognitive attitude that is reflective and that arranges knowledge about definitional credo of the term career, orders to look for a set of elements that constitutes this standpoint. It seems to be necessary for determining a range of qualities of „a career path” within a given theoretical tradition.

A weighty element of distinguished definitions of ,a career” is their distinct subjective, personal shading. As Z. Bauman states, „since a man happens to live in a given society, they want to take a chosen place; a place that suits them" (Bauman, 1960: 16). A career is always ascribed to a given individual. It is individual's assets and it is an individual who attaches importance to one's own career. We do not turn to emphasizing a practiced profession (e.g. I exercise a profession...), but we turn to „being” a representative of a practiced profession (e.g. I am...). A profession is just a context, in which individuals develop their own careers. It is common for everyone who performs work or even who looks for a job (as in case of the unemployed) (Bańka, 2005b: 25). In this sense, each subjective career has a unique character. On the basis of these assumptions, D.T. Hall underlines that a career „,is a system, a sequence of experiences of a given individual, which are linked with work (...) it is a unique system, imposed by autonomous choices" (Miś, 2006: 478). There is nothing strange about it, as individual dreams, desires, longings and imaginings concur to one's own, most personal ideal life model (Bauman, 1960: 18).

Another element of a subjective attitude is paying attention to existence of determinants that shape an individual's career. Both, objective and subjective factors, examined in isolation, do not use the full meaning of the term in question.

5 To find more abort theoretical dilemmas, linked with the definition of the notion "development", see: Zysk, 1990: 183-193. 
A holistic approach to a career development issue includes, both objective elements (i.e. duties, positions, activities, roles, professional decisions) and subjective elements (values, aspirations, attitude, expectations, needs, orientations and emotional aspect of professional experiences). Individuals who manage their careers can change objective elements of a career development environment (e.g. a change of job) or subjective elements (e.g. a change of expectations).

Following M.L. Savickas' career construction theory, which reflects constructivist perception on the subject of a career development, a career domain is seen as a central part of a subject's life and an important point of reference in shaping one's identity. The essential thing here is to treat a career choice, an ability to adapt and to develop as elements of an integrated process. The author indicates the concept of four cores: an individual life structure, an individual's professional personality ${ }^{6}$, an ability to adjust one's career, named as adaptability and a main theme of a subject's life. These four cores are essential if you want to understand individualised work behaviours. According to M. L. Savickas' career construction theory, work behaviours and their development are examined in a processual way, including their organization in a holistic, permanent and contextual way. One does not investigate an individual's career development in isolation from other dimensions, components of a subject's life. Moreover, a career (which is not a context-free component) is seen as a central dimension of a life design and, thus, it should be integrated with an individual's lifestyle (Maree, 2010: 363-364).

Savickas' career construction theory says, that ,individuals construct their theories through giving meanings to their professional behaviours and experiences" (Patton, McMahon 2006: 63). A construction of an individual's life course, which was shaped by social processes (a society and its institutions) consists of a core and supporting roles. The essential thing here is a balance between social roles of the core. Homeostasis between professional and family spheres contributes to stability, while lack of homeostasis leads to stressful situations. Personal preferences about life roles (work can be a core role, but it can also be a supporting role) are deeply rooted in social practices (Patton, McMahon 2006: 63).

As Savickas stresses, in a process of a career construction, the essence is developing and implementing professional self-concepts in work roles. Self-concepts "develop themselves through interactions of inherited abilities (...) to play various roles and abilities to assess to what degree peers and supervisors approve of role results" (Patton, McMahon 2006: 63). Thus, realization of a self-concept in a work environment is linked with a synthesis (developed from roles and learning that

${ }^{6}$ A professional personality may be shown as a desired set (syndrome, structure) of a human traits of character, formulated in a process of a professional education - nowadays, it seems more suitable to say in a process of a career development. Czarnecki, 1973: 13. 
comes from feedback information) and compromise between an individual and social factors (Patton, McMahon 2006: 63) 7 .

Nature of a discussed approach to a career course, which is its characteristic feature, is not evaluating its understanding. Lack of a comparative criterion for assessing individual justifications for choices made in a course of a professional life, makes it illegitimate to define success or its lack in the context of a career progress (Hall D.T., za: Miś, 2006: 478). In this sense, as Arthur, Hall and Lawrence (1989) put it, „everyone who works, has a career”, it indicates a neutral shading of the term career, which as a descriptive category can relate to all professions(Patton, McMahon 2006: 2). Van Maanen and Barley (1984) emphasized in their conceptualization of a career category the fact, that " «professional communities» offer an alternative for organizationally supervised hierarchies for getting a feeling of a status and achievements (...), which give sense (or at least enable adaptation) to careers, that are neither especially vertical, nor horizontal" (Thomas, 2004: 354-355).

Recalled attitudes, which point to a career category web (recognizing that it can be "vertical, horizontal, in stagnation, on a stable level, cyclic or parabolic"; Thomas, 2004: 355), visualize that this problem is difficult to capture. Career histories, in recalled works of discussed authors, are often professional career histories of given individuals, which are determined by a quality of educational and professional choices, that consist of knowledge about abilities hidden in a subject and in the world. Diversity of career paths is, thus, a result and is a sign of unpredictability of individualized experiences.

\section{Literatura}

Adekola B. (2011). Career Planning and Career Management as Correlates for Career Development and Job Satisfaction. A Case Study of Nigerian Bank Employees. "Australian Journal of Business and Management Research", No 2

Bańka A. (2005a). Motywacja osiagnięć. Poznań-Warszawa

Bańka A. (2005b). Proaktywność a tryby samoregulacji. Poznań-Warszawa

Bauman Z. (1960). Kariera. Warszawa

Biolos J. (2006). Modele kariery XXI-go wieku. [W:] Zarzadzanie kariera. Warszawa

Cybal-Michalska A. (2006). Tożsamość młodzieży w perspektywie globalnego świata. Studium socjopedagogiczne. Poznań

Czarnecki K.M. (1973). Problemy osobowości zawodowej człowieka pracy produkcyjnej. Katowice

Hejnicka-Bezwińska T. (1991). Orientacje życiowe młodzieży. Bydgoszcz

${ }^{7}$ For a synthesis phenomenon "it is not important if a role is played in a fantasy world or in a conversation with a career counselor, or in life activities, such as hobbies, various activities, clubs, half-times jobs and tasks achievement". 
Kopaliński W. (1994). Słownik wyrazów obcych i zwrotów obcojęzycznych. Warszawa

Łukaszewski W. (1984). Szanse rozwoju osobowości. Warszawa

Maree J.G. (2010). Brief Overview of the Advancement of Postmodern Approaches to Career Counseling. "Journal for Psychology in Africa" 20(3)

Melosik Z. (2007). Teoria i praktyka edukacji wielokulturowej. Kraków

Miś A. (2006). Kształtowanie karier w organizacji. [W:] H. Krol, A. Ludwiczyński. Zarządzanie zasobami ludzkimi. Warszawa

Patton W., McMahon M. (2006). Career Development and Systems Theory. Connecting Theory and Practice. Rotterdam

Zarzadzanie karierą. (2006). Tłum. D. Piotrowska. Warszawa

Rokicka E. (1992). Pojęcie „kariery”. Perspektywa strukturalno-funkcjonalna i interakcjonistyczna. „Przegląd Socjologiczny” XLI

Sarapata A. (1993). Nowoczesność Polaków. Warszawa

Sikorska-Michalak A., Wojniłko O. (1998). Słownik współczesnego języka polskiego. Warszawa

Skarżyńska K. (1990). Orientacja egalitarna i nieegalitarna. [W:] J. Reykowski, K. Skarżyńska, M. Ziółkowski. Orientacje społeczne jako element mentalności. Poznań

Thomas R.J. (2004). Blue-Collar Careers: Meaning and Choice in a World of Constraints. [W:] M.B. Arthur, D.T. Hall, B.S. Lawrence. Handbook of Career Theory. Cambridge

Wołk Z. (2009). Kultura pracy, etyka i kariera zawodowa. Radom

Zandecki A. (1996). Wykształcenie a jakość życia. Toruń-Poznań

Ziółkowski M. (1990). Orientacje indywidualne a system społeczny. [W:] J. Reykowski, K. Skarżyńska, M. Ziółkowski, Orientacje społeczne jako element mentalności. Poznań

Zysk T. (1990). Orientacja prorozwojowa. [W:] J. Reykowski, K. Skarżyńska, M. Ziółkowski. Orientacje społeczne jako element mentalności. Poznań

\section{Orientacja prorozwojowa jako determinant aktywnego współdziałania podmiotu na rzecz konstruowania własnej kariery}

\section{Streszczenie}

W artykule podjęto próbę dookreślenia kategorii pojęciowej „kariera” przy świadomości, iż jej wyróżnikiem jest różnorodność znaczeń, w których bywa używana. Nie ograniczając definicji kariery jedynie do aspektów związanych z praktyką awansów czy wykonywaniem określonego zawodu, satysfakcjonującą sytuacją zawodową jednostki czy też stabilnością wewnętrznych powiązań treści praktykowanego zawodu, uwzględniono poziom dobrostanu psychicznego podmiotu. Badanie kariery w wewnętrznym, subiektywnym wymiarze oznacza studia nad zmianami, jakie zachodzą w tożsamości podmiotu oraz jego wyobrażeniach na temat siebie i innych podmiotów życia społecznego. Nie bez znaczenia jest brak napięć dezintegrujących tożsamość podmiotu oraz dezorganizujących jego aktywność. W artykule odwołano się do współczesnych ujęć kariery, podkreślających wagę aktywności niezwiązanych bezpośrednio z pracą, takich jak: sposoby spędzania czasu wolnego, formy rekreacji, edukacja, pełnienie funkcji rodzinnych, które wiążą się zatrudnieniem (Bańka, 2005b: 26). W tym mniej restrykcyjnym podejściu do definiowania „kariery”, jak ujmuje to J.G. Maree, podkreśla się wagę konstruowania (a nie wybierania) kariery dla projektowania jakości życia. Tak rozumiana 
kariera, według D.T. Hall, oznacza sekwencję doświadczeń jednostki związanych z pełnioną przez nią funkcją zawodową, składającą się na jej historię życia zawodowego. Jak ujmuje to A.S. King, „psychologiczna siła własnej tożsamości, wgląd w siebie i wytrzymałość w dążeniu do realizacji celów kariery reprezentują główne komponenty motywacji i «poświęcenia» (rozumianego jako zaangażowanie - dop. A.C-M) się karierze, a także współpracy, spoistości (...) w organizacji” (Adekola, 2011: 104). Jednostka jako indywiduum nadaje swoiste indywidualne znaczenia wybranym elementom rzeczywistości dzięki umiejętności odczytywania kodów kulturowych, stwarza własną indywidualną historię i ma przed sobą przyszłość. Konstruuje własne życie, a tym samym - osobistą karierę „poprzez identyfikację (nadawanie znaczeń) z własnymi zawodowymi zachowaniami i licznymi doświadczeniami w miejscach pracy" (Maree, 2010: 363), nadając także znaczenie kontekstowi, w którym owe doświadczenia zachodzą. Powzięcie przez jednostkę odpowiedzialności za poszukiwanie znaczenia swojej roli w praktykowanym zawodzie, którego źródłowość Ch. Handy, autor pracy zatytułowanej The Age of Paradox, upatruje w kierunku (jednostkowe poczucie działania w słusznej sprawie), ciągłości (wiara podmiotu w przetrwanie i kontynuowanie wytworów jego pracy) oraz łączności (udział we wspólnocie, z którą się identyfikujemy i współtworzymy), jest procesem całożyciowym i zadaniem całożyciowego uczenia się (Zarządzanie karierą, 2006: 11). Brytyjski uczony dodaje, że „znaczenie przyjdzie do tych, którzy rozwijają własne poczucie kierunku, ciągłości i łączności” (Biolos, 2006: 30) w tym, co zawodowo praktykują. W tym kontekście nie bez znaczenia jest jakość ukształtowanej orientacji prorozwojowej podmiotu. Kontekst, w jakim używa się pojęcia „orientacja”, w najogólniejszym ujęciu oznacza umiejętność oceny, rozeznania i interpretacji sytuacji, znajomość faktów i skłanianie się ku czemuś (zob. Kopaliński, 1994: 368; Sikorska-Michalak, Wojniłko, 1998: 688). Termin ten bywa definiowany jako „zdolność do prawidłowego i szybkiego ustalania danych zewnętrznych oraz danych związanych z własną osobą i kierunkiem celowego działania” (Hejnicka-Bezwińska, 1991: 16). Istotę działań prorozwojowych, w ogólnym ujęciu, stanowi działanie (jednostki) nastawione na realizację pewnej wizji stanu idealnego. T. Zysk, powołując się na W. Reykowskiego i J. Kozieleckiego, podkreślił, że najbardziej kluczową i charakterystyczną właściwością ludzkiego umysłu jest zdolność do formułowania wizji przyszłych stanów rzeczy. Podmiot jest przekonany o doskonałości owego stanu i podejmuje działania zmierzające do jego realizacji (Zysk, 1990: 199). Do właściwości psychologiczne warunkujących zachowania prorozwojowe T. Zysk zaliczył motywację wewnętrzną, nastawienie na przyszłość oraz aktywne radzenie sobie z rzeczywistością. Szczególne znaczenie przypisał dwóm pierwszym czynnikom.

Istotę stanowi sekwencyjny rozwój jednostki (integralnie związany z rozwojem jej kariery) w trakcie całego życia jednostkowego. Ważkim elementem wyróżnionych definicji ujmowania „kariery” jest ich wyraźne podmiotowe, personalne wycieniowanie oraz zwrócenie uwagi na istnienie uwarunkowań kształtowania kariery jednostki. W myśl teorii konstruowania kariery M.L. Savickas’a odzwierciedlającej konstruktywistyczne spojrzenie na rozwój kariery, domena kariery jest postrzegana jako centralna część życia podmiotu i ważny punkt odniesienia w kształtowaniu jednostkowej tożsamości. Istotę stanowi traktowanie wyboru kariery, umiejętności przystosowania się i rozwoju jako elementów zintegrowanego procesu. Autor wskazuje na koncept czterech rdzeni: strukturę życia jednostki, jej osobowość zawodową, umiejętność przystosowania kariery zwaną adaptacyjnością oraz temat przewodni życia podmiotu, dla zrozumienia zindywidualizowanych zachowań zawodowych. W teorii konstruowania kariery M.L. Savickas'a zachowania zawodowe i ich rozwój są rozpatrywane procesualnie z uwzględnieniem ich organizowania w sposób holistyczny, permanentny i kontekstualny. Rozwoju kariery jednostki nie rozpatruje się w izolacji od innych wymiarów, części składowych życia podmiotu. 
Co więcej, kariera (niebędąca częścią bez-kontekstową) postrzegana jest jako centralny wymiar projektowania życia, toteż powinna zostać zintegrowana ze stylem życia jednostek (Maree, 2010: 363-364). Teoria konstrukcji kariery autorstwa Savickasa głosi, że jednostki konstruują swoje kariery poprzez nadawanie znaczeń swoim zawodowym doświadczeniom. Konstrukcja biegu życia jednostki, która została ukształtowana przez procesy społeczne (społeczeństwo i jego instytucje) składa się z rdzenia i ról drugoplanowych. Istotę stanowi równowaga pomiędzy rolami społecznymi rdzenia. Homeostaza pomiędzy sferą zawodową a rodzinną przyczynia się do stabilności, podczas gdy jej brak wywołuje sytuacje stresujące. Osobiste preferencje co do ról życiowych (praca może pełnić funkcję rdzenia, ale może też pełnić funkcję drugorzędną) są głęboko zakorzenione w praktykach społecznych. W procesie konstruowania kariery, jak podkreśla Savickas, istotę stanowi rozwijanie i wdrażanie zawodowych autoidentyfikacji w podejmowane i pełnione role zawodowe. Realizacja koncepcji samego siebie w środowisku pracy wiąże się z syntezą (rozwijaną na gruncie odgrywania swojej roli i z nauki płynącej z informacji zwrotnej) oraz kompromisem pomiędzy jednostką a czynnikami społecznymi (Patton, McMahon, 2006: 63).

Przywołane stanowiska, uświadamiające splot kategorii kariery przy uznaniu, iż może być ona $\mathrm{z}$ orientacją prorozwojową, unaoczniają, iż historie kariery to $\mathrm{w}$ istocie historie kariery zawodowej poszczególnych jednostek determinowane przez jakość ich orientacji prorozwojowej ujawnianej na poziomie wyborów edukacyjno-zawodowych, na które składała się wiedza o możliwościach tkwiących w podmiocie i zastanych w świecie. Różnorodność ścieżek kariery stanowi zatem rezultat i jest przejawem niepowtarzalności zindywidualizowanych doświadczeń. 